\title{
Exploring Situated Learning through Task based Activities: A Case Study in the Mandarin Class
}

\section{Mok Soon Sim, Noor Hanim Rahmat, Lau Suk Khin}

To Link this Article: http://dx.doi.org/10.6007/IJARBSS/v11-i12/11374

DOI:10.6007/IJARBSS/v11-i12/11374

Received: 15 October 2021, Revised: 18 November 2021, Accepted: 01 December 2021

Published Online: 19 December 2021

In-Text Citation: (Sim et al., 2021)

To Cite this Article: Sim, M. S., Rahmat, N. H., \& Khin, L. S. (2021). Exploring Situated Learning through Task based Activities: A Case Study in the Mandarin Class. International Journal of Academic Research in Business and Social Sciences, 11(12), 1654-1676.

\section{Copyright: (c) 2021 The Author(s)}

Published by Human Resource Management Academic Research Society (www.hrmars.com)

This article is published under the Creative Commons Attribution (CC BY 4.0) license. Anyone may reproduce, distribute, translate and create derivative works of this article (for both commercial and non0-commercial purposes), subject to full attribution to the original publication and authors. The full terms of this license may be seen at: http://creativecommons.org/licences/by/4.0/legalcode

$$
\text { Vol. 11, No. 12, 2021, Pg. } 1654-1676
$$

Full Terms \& Conditions of access and use can be found at http://hrmars.com/index.php/pages/detail/publication-ethics 


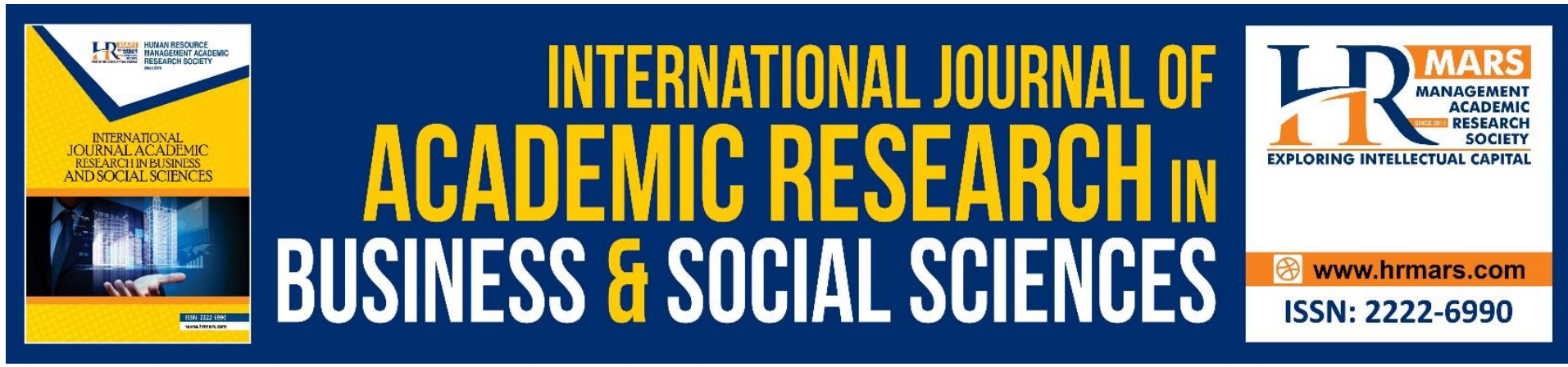

\title{
Exploring Situated Learning through Task based Activities: A Case Study in the Mandarin Class
}

\author{
Mok Soon Sim ${ }^{1}$, Noor Hanim Rahmat ${ }^{2}$, Lau Suk Khin ${ }^{3}$ \\ ${ }^{1}$ Akademi Pengajian Bahasa, Universiti Teknologi MARA, Shah Alam, Malaysia, ${ }^{2} A k a d e m i$ \\ Pengajian Bahasa, Universiti Teknologi MARA cawangan Johor, Kampus Pasir Gudang, \\ Malaysia, ${ }^{3}$ Akademi Pengajian Bahasa, Universiti Teknologi MARA, Shah Alam, Malaysia \\ Email:moksoon@uitm.edu.my,noorh763@uitm.edu.my, lausuk@uitm.edu.my
}

\begin{abstract}
This is a pilot study that exposes non-native Mandarin speakers to native speakers directly in the Malaysian Chinese community. It aims to examine the application of situated learning theory via task-based activities in authentic situation. 30 students participated in this qualitative case study. They were purposely chosen from 5 classes of students in a public university who attended a Mandarin class for a semester. Data is collected from the learners' conversations. The conversation is recorded in the form of transcripts to be analysed qualitatively. Codes were used indicate the type of factors evident in the conversation. The study is rooted from the theory of situated learning by Lave \& Wenger (1991). The theory reveals that learning involves social interaction in a real and authentic context to allow learners to create their own knowledge using the constructivist approach. The three factors in Lave \& Wenger's (1991) theory are used to scaffold the items in task-based learning by Ellis (2009). The study findings firstly prove that authenticity is achieved in task-based approach using natural language. Next, social interaction is fulfilled when the activities are focused on learner-centredness through communicative tasks. Finally, learners build their knowledge through constructivism by rejecting traditional teaching and focusing on the form in the conversations. The research findings can help Mandarin instructors to modify their teaching methods, create appropriate tasks and improve the Mandarin textbook.
\end{abstract}

Keywords: Situated Learning, Task-Based Activities, Mandarin, Authenticity, Social Interaction

\section{Introduction}

Background of Study

This study is based on an increasing awareness of the importance of Mandarin language worldwide. More and more non-native Mandarin learners are keen to learn the language to improve their global communication skills. Mandarin instructors thus play an important role to adopt suitable teaching approach to bring the greatest advantage in achieving learning outcome in the classroom. 
Task-based Language Teaching (TBLT) approach is a new approach in education practice. In task-based classroom, the focus is on task execution. The task is not a grammatical unit that needs to be digested or a collection of lexical items to be memorized, but a means of learning the language by doing tasks. It needs exposure to comprehensive input and opportunities to interact in the language (Mao, 2012). The activities in the task should be linked to the daily work, or in other words, the task should focus on real-life situations as defined by Long (1985):

\begin{abstract}
"A task is a piece of work undertaken for oneself or for others, freely or for some reward. Thus, examples of tasks include painting a fence, dressing a child, filling out a form, buying a pair of shoes, making an airline reservation, borrowing a library book, etc. In other words, by 'task' is meant the hundred and one things people do in everyday life, at work, at play and in between"
\end{abstract}

The utilization of TBLT is very prominent in the teaching of English as a second language. However, to date, the usefulness of TBLT in education in Asia and other international settings has not yet been convincingly proven (Carless, 2009).

In Malaysia, the learning of Mandarin language among non-native speakers were mostly implemented in the classroom, not in the real-life. This study is a pilot study that exposes nonnative Mandarin speakers to native speakers directly in the Malaysian Chinese community. It aims to examine the application of situated learning theory via task-based activities in authentic situation. The samples are undergraduate students who are taking Mandarin course at University of Technology MARA (UiTM) Shah Alam campus. The respondents were assigned task to buy clothes, watches, stationaries, shoes, food, and drinks in locations where they can communicate with native Mandarin speakers.

\title{
Statement of Problem
}

According to Rubin (1949), communication is a way of receiving and sharing meaning through the exchange of messages. Therefore, mastering good Mandarin speaking skills is essential for non-native speakers to convey their messages clearly.

Lü (2005) defined different scopes of teaching Mandarin language skills to communicate. In his opinion, traditional teaching of Mandarin is based on pronunciation, vocabulary, grammar, but in the teaching of Mandarin speaking skills, attention should be given to dialogue situations, conversation topics, specific language functions such as greetings, selfasking and expressing feelings, other aspects of language in speech. Obviously, he emphasized more the function and use of language to communicate.

Cui (2008) stated that language is used for communication, and the activities that students learn in the language classroom should be activities that 'use' the language. This means that the activities should be as communicative as possible. A variety of group activities can be designed for language lessons, such as two-person conversations, role-playing, group work, group discussions, debates, performances, etc. The organization of group activities not only helps to develop communicative skills. It can also broaden the range of learners' activities, increase the rate of classroom talk, improve communicative boldness, learn to interact with others and constantly acquire new information. 
Jiang (2009) believed that in second language teaching, teachers should not only impart knowledge and training skills in the classroom but more importantly, organize and guide students to use the knowledge and skills they have learned to communicate. Therefore, only by engaging students in a variety of communicative activities in the classroom, so that they can experience and use the second language, only then the knowledge and skills learned to be transferred effectively and students' communicative competence be truly developed.

However, it is found that non-native speakers of Mandarin often have difficulty in speaking the language. Yang (1996) categorizes the problems faced by non-native speakers of Mandarin as follows: 1) misspelling 2) lack of vocabulary 3) grammatical errors 4) paragraph inconsistencies, and 5) fluency. Khor et al (2013) in their research found that the undergraduates were suffering from mastering the Mandarin pronunciation, which had been greatly influenced by Malay language as their mother tongue. The study also found that nonnative Mandarin speakers have difficulty communicating with others in real life. In another research done by Jafri \& Abd Manaf (2020), it was found that students are reluctant to use Mandarin to express their opinions during teaching and learning. Students also did not have the confidence to use Mandarin to communicate with strangers or outside the classroom.

In Malaysia, UiTM has the biggest number of Malay students learning Mandarin as a foreign language in the country. According to the statistics (Mok et al., 2019), there were 788 Malay students studying the Mandarin language in the main campus in UiTM in 1994. This number has increased to more than 18,000 in the main campus and all branches nationwide now. The ultimate purpose of teaching Mandarin as a foreign language in UiTM is to improve the learner's oral communication ability. Therefore, one of the learning outcomes of the Mandarin language course in UITM is to "emphasize greatly on developing participants oral communication skills in situational contexts through class activities such as role plays, simulations, and other relevant oral tasks." Students should participate in all language activities in the classroom to ensure that they successfully reach the elementary level proficiency. Hence, the text in the textbook is also conducted in the form of a dialogue (Mok et al., 2021). But the students' ability to communicate with Mandarin native speakers outside the classroom has never been assessed. Even though simulation and role-play are adopted as assessments in the classroom, but the result does not reflect the actual speaking skills of the students when they are in the real-life situation.

Therefore, some teaching approaches should be adopted to enhance the communication skills among non-native speakers of Mandarin.

Yang (1996) suggested teaching strategies that improve students' speech. According to him, the instructors or providers of the teaching module should focus on students' communication skills. He suggested the provision of teaching materials based on the need for communication.

Bao and colleagues (2008) in an article entitled "Strategies of Chinese vocabulary teaching in view of communication norms" have suggested ways of improving students' communication skills. In her opinion, the main goal of Mandarin language teaching and learning for non-native speakers is to enable students to speak Mandarin and communicate with the native speaker community. Therefore, all content of the syllabus and training should focus on this objective. Vocabulary teaching plays an important role in teaching Mandarin as a foreign language. To 
develop Mandarin speaking skills among non-native speakers, educators should focus on student's speaking problems, distinguishing students' differing needs at different levels, emphasizing the use of language as the ultimate objective of achieving teaching and learning effectiveness.

This opinion was supported by Jia in 2005 and Zheng in 2007. Jia (2005) stated that communication is the most effective method that is often applied in improving the quality of Mandarin language teaching and learning to non-native speakers. The advantage of the communication method is that it aims to foster the ability to communicate of students. In the real role-play or classroom role play, teachers can practice teaching oral skills based on the content of the communication. Zheng (2007), in turn, argues that oral skills are an important aspect of teaching Mandarin as a foreign language. Students need to master the pronunciation and grammar of the Mandarin at a certain level and then must learn how to use those skills to communicate effectively. In the teaching of oral skills, students are taught grammar repeatedly and systematically. Thus, the level of mastery of oral skills can be improved.

Chen (2006) in a study conducted in Taiwan stated that teaching Mandarin as a second language is not only necessary to convey knowledge of the language, but more importantly, to strengthen skills training to enable students to interact effectively. Chen conducted experiments by applying technology in the teaching of Mandarin. He had selected non-native speakers from abroad as his study samples. The study samples were divided into 2 groups, one experimental group and the other control group. Experimental group was exposed to examples of dialogues in multimedia shows while controlled groups was taught in the traditional way of teaching. Study samples in the experimental group were encouraged to interact with each other according to the examples in the show. In addition, the study samples were also asked to write their own dialogue based on the vocabulary and sentences displayed on the computer. Finally, the study samples were required to present their dialogue in the classroom. The presentations were recorded with video and digital cameras. The findings show that the experimental group obtained higher evaluation scores than the control group. Thus, Chen concludes that interactive teaching enhances students' interest and confidence in learning Mandarin.

From the above studies, it is important to note that speaking skills are important in determining the level of Mandarin proficiency among non-native speakers. Methods have been proposed to strengthen the language proficiency among non-native speakers of Mandarin. However, there is still lack of research that examines the speaking skills of Mandarin non-native speakers through communication with Mandarin native speakers in real life.

\section{Objective and Research Question}

Generally, this study explores the use of task-based learning in the learning of Mandarin. Specifically, this study intends to answer the following questions:

- How is authenticity portrayed in task- based learning?

- How does task-based learning encourage social interaction?

- How does task-based learning encourage learning through constructivism? 


\section{Literature Review}

Approaches to the Teaching of Mandarin

Teaching Mandarin to the beginners who learn Mandarin as a foreign language is quite challenging. Due to some characteristics of Mandarin language, such as the uniqueness of Mandarin tones, the uniqueness of Chinese characters, the lack of obvious morphological signs, etc., it naturally affects the teaching approaches of the learning process. Therefore, the teaching of Mandarin as a foreign language in the classroom will accordingly have different techniques and focus.

As suggested by Zhao (2011), teaching of Mandarin as a foreign language should include the teaching of phonetics, vocabulary, grammar, and Chinese character. Zhao further pointed out the teaching of phonetics is at the first level of the teaching and learning process. It should consider the pedagogical principles of practicality, interesting, and integration with other elements. This opinion is supported by Trísková (2017) who mentioned that the foundation of pronunciation is obtained at the beginning of the second language learning, when the new phonetic system of the second language has been established in the learner's mind. If beginners make mistakes in speech production, if unattended, they can easily become fossils due to the continuation of bad pronunciation habits, and the phonetic/language sense between languages may stop developing. Therefore, the teaching of pronunciation in a second language requires a well-designed teaching method, careful planning of successive steps, and careful coordination with other teaching goals.

Indeed, in the 1960s, good pronunciation of Mandarin among the beginners was the primary concern. Drilling exercises and the "listen and repeat" method were generally used as the learner will find that the fluency obtained through mechanical repetition is a huge lubricant for understanding the content of the speech (Chao, 1925). Later, with the rise of "Communicative Language Teaching" (Halliday, 1973 and Hymes, 1971) and "Natural Approach" in the 1970s and early 1980s (Terrell, 1977 and Krashen, 1983), attention to pronunciation teaching declined. These approaches try to reflect the process of natural language acquisition in the classroom. Emphasis is placed on developing communicative skills. This practice caused a lack of pronunciation emphasis in teaching materials. The result of the communicative approach was that the second language speakers usually grew up with good communicative skills and self-confidence but were left many rigid errors in their interlanguage. Since the 1990s, the approach called "form-focused instruction" (FFI) has been promoted. It acknowledged the usefulness of communicative principles in second language teaching and emphasized the clear guidance on linguistics forms and rules (Spada \& Lightbrown, 2008). In the past 20 years, people have developed great interest in pronunciation teaching in second language teaching again, supported by the further development of technology. However, the traditional "listen and repeat" approach will always have an important role to play. It cannot be removed from teaching as it can equip students with the ability to communicate in language.

Lu (2010) highlighted some issues concerning the teaching of Mandarin phonetics to foreign learners, such as the importance of phonetic, the role of phonetic theory, importance of stress and intonation rules and the application of the Scheme for the Mandarin Phonetic Alphabet (Mandarin Romanization). Finally, he has made 9 suggestions on the principles guiding the teaching of phonetics, that is: a) capture the focus, b) easy first and then difficult, $c$ ) the front 
should set the stage for the back, d) phonics teaching with word grammar and vocabulary, e) exercises should avoid using meaningless syllables as much as possible, preferably using words, phrases, short sentences, etc. that students have learned, f) try to exclude as much as possible in teaching to eliminate possible misunderstandings of students, g) phonics practice should be scheduled for at least one semester, not just one or two weeks of the so-called phonics phase, h)teaching should be focused, and i) phonics teaching should inspire students' learning motivation, guide them to discover the rules by themselves and learn consciously.

Regarding the teaching of Mandarin vocabulary, Cui (1997) divided the teaching techniques into techniques for presenting vocabulary, techniques for explaining vocabulary, techniques for practicing vocabulary, and techniques for building vocabulary. Subsequently, Lü (2007) suggested that Mandarin vocabulary teaching should involves vocabulary control, word selection, word meaning interpretation and vocabulary practice methods. Li (2017) also agreed that vocabulary teaching has always been one of the most difficult barriers to overcome in teaching Mandarin as a foreign language. In this regard, there are debates on the "morpheme", "character" and "word" bases, and each school of thought has justified its claim with its own theoretical basis. There are different opinions on which claim is more effective in the vocabulary teaching. Li considered the debate on the originality of teaching Mandarin as a foreign language is basically not of much value. The actual teaching effect depends entirely on the teachers' reasonable and flexible use. The use of the specific characteristics of Mandarin vocabulary itself is the only way to improve the teaching of Mandarin as a foreign language. Thus, he tried to examine the topic-based teaching can promote the acquisition of Mandarin vocabulary from the perspective of "three-dimensional view", the "error-preventing" and "limited radiation" strategies. The results show that this teaching method is evidently effective. In addition to that, Zhang (2015) proposed the instructors must explain the vocabulary in different situation to make the learners understand because some Mandarin vocabularies have several meanings. The instructors can tell learners that one or two core meanings are frequently used, but other meanings can be ignored at the initial stage. For instance, the primary meaning of “深 (shēn)" is "deep" which can be used to describe water. However, this vocabulary also means "hard to understand". If the instructor tries to introduce these different meanings to the learners in one lesson, it can make learners confused. However, if the instructor could just focus on one specific linguistic meaning (deep), it will be making the learning more transferable.

In teaching Mandarin grammar, however, the approaches might be different. The overall goal of teaching Mandarin grammar to foreign learners is to develop their ability to form words and sentences in Mandarin and connect them into Mandarin expressions. The composition of this ability is not single, but involves three aspects: syntax, semantics and pragmatics. From the analysis of wrong sentences in the 1970s (Tong, 1986 and Cheng et al., 1997), to the analysis of errors that emerged in the mid-1980s (Lu, 1984), to the study of grammar acquisition patterns of Mandarin learners that has gradually developed since the 1990s (Wang, 1997 and Shi, 1998), the approaches for teaching Mandarin as a foreign language has been further expanded. In 2013, Williams examined the efficiency of three types of Chinese grammar teaching materials: text-only, text-picture, and text-video. The study was carried out among 53 beginning and intermediate-level Mandarin language students at a public university in Massachusetts by means of immediate and delayed tests. Results revealed that text-video has an obvious positive effect on Mandarin grammar comprehension generally. 
Compared with text-only, text-video has a direct performance enhancement, but has no obvious enhancement in the long run. The results also showed that when the target form becomes more complex, text-video is more effective than text-picture in comprehension of Mandarin grammar.

Apart from the pronunciation, vocabulary and grammar, Chinese has been considered as one of the most challenging writing systems to be learnt by non-native Chinese learners because of its complex orthographic structure (Shen, 2005). According to Everson (1998), the difficulty to read Chinese characters is because it does not use an alphabet. To learn Chinese characters, learners must become conscious of the characters' visual shapes, learn stroke orders, and gain a knowledge of the radicals' functions and positions within a character (Everson, 2009; Feldman \& Siok, 1999; Hayes, 1988; Perfetti, Ying \& Tan, 2005). Basically, there are 3 main approaches in the teaching of Chinese character: a) focus on Pinyin, (b) focus on writing, and c) focus on recognition.

Pinyin is the Romanized transliteration of spoken Mandarin. The studies conducted by Everson (1988) and Packard (1990) showed that learners performed better on reading and speaking tasks when using Pinyin instead of characters in the learning. Advocates who focus on writing emphasis character writing in the classroom. A study found that by demanding learners to write characters instead of simply recognizing them, learners perform better in reading tasks (Guan et al., 2011). Guan and colleagues believed that this was a result of motor memory accelerating memory of characters. They explain that "once motor memory has been learned and stabilized, it can last for very long periods of time". As Chinese character writing exercises take up a large part of the learning time, some researchers suggest that instructors focus on character recognition rather than writing (Allen, 2008; Xu \& Jen, 2004; Ye, 2013). Hence, Chinese characters can still be taught, but the time pressure that writing characters can be cut down. Harrington and Jiang (2013) conducted a study to examine the effectiveness of this approach. They required learners to pay attention to the form of characters by recalling tasks at the beginning of each lesson. It turns out that by stimulating the retrieval of character forms, learners are forced to focus on the characters. Consequently, their performance in character recognition tasks has enhanced.

Poole \& Sung (2015) intended to compare the effect of three teaching approaches (focus on Pinyin, focus on writing and focus on recognition) in an experimental setting on learners' oral and character recognition performances. This study involved nine first-year Mandarin learners at a university in the United States. The results of character quizzes and oral assessment of the participants was collected as the data. Participants and their teachers also took a survey to find out their views on each teaching approach. The survey results show that some teaching methods help students develop oral skills more quickly than others, while some methods are more effective in helping to develop character recognition. 


\section{Situated Learning}

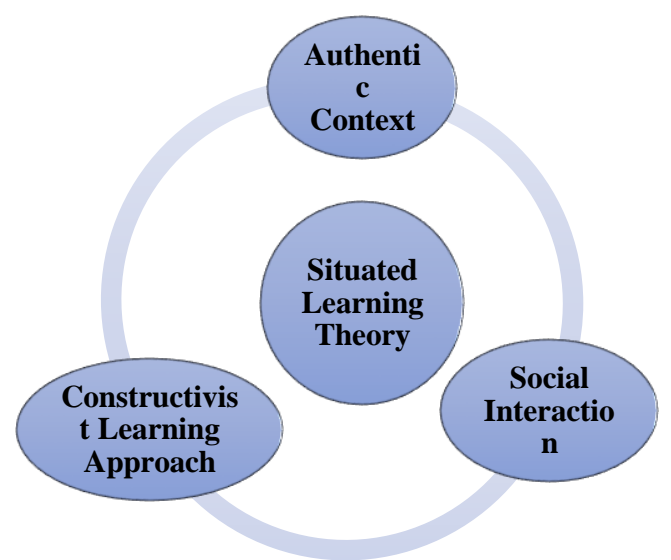

Figure 1: Situated Learning (Source: Lave \& Wenger, 1991)

Based on figure 1 above, situated learning theory explains human action is adapted to their environment. The theory also states that what people learn is situated in their roles as a member of the community around them. Lave \& Wenger (1991) explain that learning involves social interaction using authentic context. The interaction enables the learners to build their own learning through the constructivism. Constructivism is based on the idea that through interaction with others and interaction with the environment, people learn to manage /construct their own knowledge. This knowledge is determined by their experiences.

\section{Task-based Approach}

Task-based approach is used in the teaching and learning of second/foreign language learning where the focus is on classroom tasks. Students who participate in task-based learning learn to solve tasks that are relevant and interesting to them. Interestingly, in order to solve the tasks, the learners learn to communicate with their peers. These learners use authentic language instead of concentrating on grammar or vocabulary. Ellis (2009) presented five characteristics in task-based approach. Firstly, learners need to focus on natural language use. Next, the activities are planned by the teacher so that it focuses on the learner. In addition to that, the activities are also geared to focus on the form-the use of the target language-even though the main focus is meaning making. Task based approach concentrates on the use of communicative task to allow natural interaction. Finally, this approach rejects the traditional approaches that focused on passive formal instructions.

\section{Past Studies}

Past Studies using Task Based/Situated Learning to learn Mandarin

In the study of Lin et al (2014), the researchers intermixed two task-based language teaching (TBLT) approaches in the 3D multiuser virtual environment (MUVE) Second Life and examined the advantages and challenges from the viewpoint of an expert user in Australia and three native users in Taiwan. In this qualitative research, the participants included the four instructors from two countries and 144 Chinese language undergraduate students at a major Australian university. Three activity units based on information gap and reasoning gap teaching tasks were set up. It was found that conducing TBLT in Second Life can assist instructors create chances for the students to set clear objectives, provide student-centered and reliable approaches to learning, and bring numerous opportunities for input, production, and reaction. Apart from that, the lesson composition (with the expert paying attention to 
the technical issues in the physical classroom and the content instructors focusing on teaching virtually) helped decrease frequent technical issues in Second Life and thus build up comfortable learning environment for both the instructors and students to merely concentrate on the learning content of the language class.

Zhou (2016) studied the application of TBLT in introductory level Mandarin classes at The College of The Bahamas. Zhou admitted that the ideas and principles of TBLT has proven to be effective in classrooms. The three pedagogic goals of task-based approaches: communication, restructuring and fluency, are also the goals of Mandarin learners. TBLT was helpful to the Bahamian learners to improve their Mandarin skills by completing various activities and tasks within the task-based framework. Observations and results obtained through using this strategy have shown that TBLT is effective in Mandarin classroom for Bahamian adult learners.

Meng (2020) conducted a research on the application of situational teaching method in teaching Mandarin online new words in Mainland China. The respondents were intermediate and advanced level of Mandarin foreign learners. By using different type of lessons, the researcher developed the situational teaching method in learning the Mandarin online new words. The findings showed that the situational teaching approach helped learners to master online new words and communicate more effectively through the setting of concrete situations.

In a study by Rahmat, Mok, Lau \& Fan (2020), the researchers found that to bring "real-life" environment into the classrooms, teachers can plan "simulation" activities as part of the classroom routine. Simulation activities allow learners to gain "hands-on" experience in the form of experiential learning. One way to enable learners to learn through interaction in "reallife" environment is by using simulation. The quantitative study explored the use of simulation in learning Mandarin. 20 non-native Mandarin speakers from a Malaysia public university had answered survey with 11 items on a 5-point Likert-scale. Findings informed that activities done during simulation illustrated the benefits of experiential learning. Simulation produces pseudo-authentic environment. Learners sometimes have a feeling of being in a real environment. In addition, the social interaction that takes place allows more levels of learning to take place.

Past Studies on Learning Mandarin using Technology

Technology has indeed brought a revolution to language learning, but it is a tool that requires skill to use. Previous research has shown that plenty of alternative language learning tools are being invented using technology. In the study of Chen \& Chung (2011), it explored the effect of multimedia-assisted teaching on Vietnamese students' Chinese vocabulary learning and understand the difficulties encountered by Vietnamese students in the process of multimedia-assisted teaching and learning. The electronic flashcard of Mandarin vocabulary and the digital version of the Chinese-English Picture Dictionary is used as the teaching materials of this study. They found that the content of the disc using as a classroom teaching aid in the way of scenario simulation was very appropriate for Vietnam's students. It also provides various digital diversification exercises. It is very good teaching material to make students familiar with these contents naturally and for them to learn independently. Students can also practice repeatedly by themselves through multimedia exercises to train their 
reaction capacity, and they can gain unlimited learning capacity beyond the limited teaching time.

Zhan \& Cheng (2014) presented a technology-enhanced Chinese character teaching model (REEE) in the classroom. This model consisting of four stages: (1) radical awareness, (2) enforcement of sound and meaning connections of characters, (3) enforcement of sound, meaning and form connections of characters, and (4) evaluation. The first stage is carried out before class. The instructor will make an animated vocabulary Power Point, which will display word information in the order of English translation, pinyin, Chinese characters, radical and specific vocabulary. According to the design sequence of the Power Point, the instructor will make a video to explain the vocabulary of Power Point and explain it in Mandarin according to the students' Mandarin proficiency. The second stage includes many teaching and learning activities to help establish the pronunciation and meaning of Chinese characters. The third stage includes many teaching and learning activities to help establish the connection between phonetics and characters. The fourth stage is carried out at the end of each class to assess learning and teaching. Research has found that this model can effectively save classroom interaction time and attract students to participate in the learning process.

Ju \& Mei (2020) explored students' attitudes and views on learning Mandarin through animated videos at the beginner level. In this study, animated videos are used to create the content of online courses, combined with basic Mandarin vocabulary and sentence structure to improve learning effects. The content involved in the course integrates basic Mandarin vocabulary and sentence structure, which improves the learning effect. The researcher found that students maintain a positive attitude toward learning Mandarin through animated videos. The students said that the animated video not only improved their listening and speaking skills, but also helped them learn Mandarin vocabulary and sentence structure. The results of this research also show that animated videos provide Mandarin teachers with a large amount of Mandarin vocabulary and sentence structure.

Conceptual Framework of the Study

The study is rooted from the theory of situated learning by Lave \& Wenger (1991). The theory reveals that learning involves social interaction in a real and authentic context to allow learners to create their own knowledge using the constructivist approach. The three factors in Lave \& Wenger's (1991) theory are used to scaffold the items in task-based learning by Ellis (2009). With reference to figure 2, Authenticity is achieved in task-based approach through the use of natural language. Next, Social Interaction is fulfilled when the activities are focused on learner-centredness through communicative tasks. Finally, learners build their knowledge through Constructivism by rejecting traditional teaching and also focusing on the form in the conversations. 


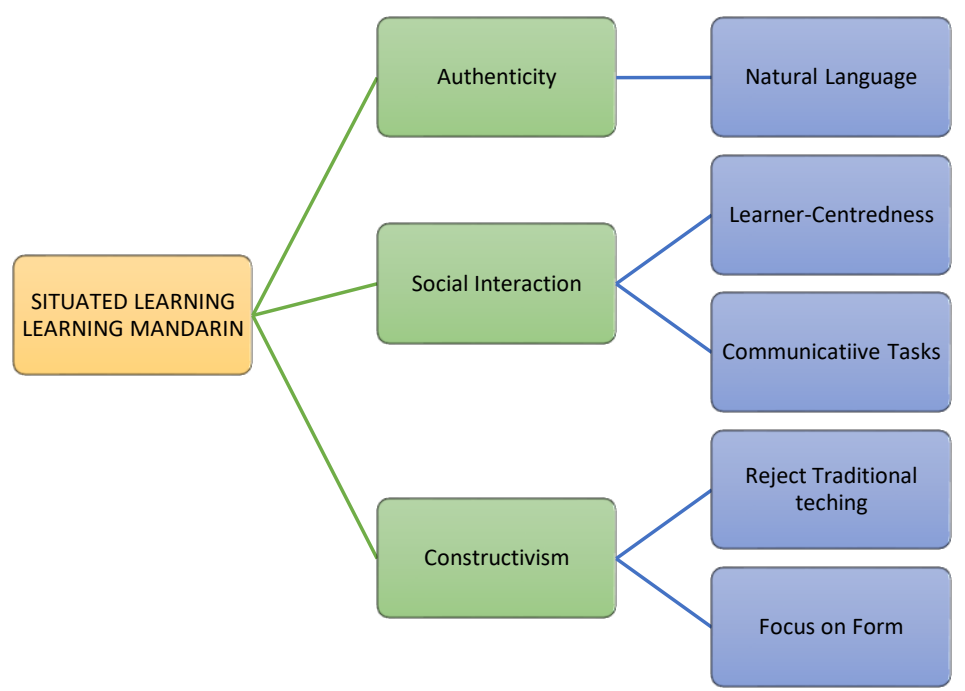

Figure 2-Conceptual Framework of the Study-Situated Learning in learning Mandarin (Source: Lave \& Wenger, 1991and Ellis, 2009)

\section{Methodology}

This qualitative case study is done to explore situated learning in the Mandarin classroom. 30 students participated in this study. They were purposely chosen from 5 classes of students in a public university who attended a Mandarin class for a semester. Data is collected from the learners' conversations. The conversation is recorded in the form of transcripts to be analysed qualitatively. Codes were used indicate the type of factors evident in the conversation. Table 1 shows the factors in situated learning and their relationship to task-based factors.

Table 1-INSTRUMENT FOR CHARACTERISTIC OF TASK-BASED LEARNING (Ellis, 2009)

\begin{tabular}{|c|c|c|c|}
\hline \multirow[t]{2}{*}{ NO } & FACTORS IN & CHARACTERISTICS OF & DESCRIPTION \\
\hline & $\begin{array}{rr}\text { SITUATED } & \text { LEARNING } \\
\text { (Lave \& } & \text { Wenger, } \\
1991)\end{array}$ & $\begin{array}{r}\text { TASK BASED LEARNING } \\
\text { (Ellis, 2009) }\end{array}$ & \\
\hline 1 & AUTHENTICITY & Natural Language use & do not focus on accuracy (authentic) \\
\hline \multirow[t]{2}{*}{2} & \multirow[t]{2}{*}{ SOCIAL INTERACTION } & Learner-Centredness & focus on the learners' abilities \\
\hline & & Communicative tasks & task encourage interaction \\
\hline \multirow[t]{2}{*}{3} & \multirow[t]{2}{*}{ CONSTRUCTIVISM } & $\begin{array}{r}\text { Rejection of Traditional } \\
\text { Approaches }\end{array}$ & $\begin{array}{l}\text { where they focus on passive formal } \\
\text { instruction and practice isolated from } \\
\text { communicative work }\end{array}$ \\
\hline & & Focus on form & $\begin{array}{l}\text { attract students' attention to linguistic } \\
\text { components as they emerge } \\
\text { accidently in lessons whose main } \\
\text { focus is on meaning or communication }\end{array}$ \\
\hline
\end{tabular}

\section{Findings}

Introduction

This section presents the findings by answering the three research questions presented above. 
Findings for Authenticity (Natural Language)

This section presents answers to Research Question 1: How is authenticity portrayed in taskbased learning?

TBLT focuses on the use of authentic language to carry out meaningful tasks in the target language (Zhou, 2016). The tasks given to the respondents in this study was like "a goaloriented activity in which learners use language to achieve a real outcome" (Willis, 1996). To achieve a real outcome, sometimes the respondents used the language in authentic situations naturally, without using all the vocabulary and structures taught by the instructors. This fulfilled the features of TBLT approach as described by Nunan (1991), that is "the introduction of authentic texts into the learning situation".

The examples of natural language used by the respondents in this study can be observed through the excerptions from conversation below:

Pair 1

Speaker A: Hăode, nà wǒ xūyào fù duōshao qián?

(Good, so how much should I pay?)

Speaker B: Dǎzhé hòu zhè pǎoxié liăng bǎi wǔshí kuài qián.

(After discount, this running shoe RM250.)

In proper Mandarin grammar, "this pair of running shoes" should be translated as "zhè shuāng pǎoxié". "Zhè shuāng pǎoxié" is a Mandarin Endocentric Phrase (MEP). MEP is a type of Mandarin phrase which is classified according to its internal structure. It is formed by two components which share a [modifier-head word] relationship. The modifier component precedes the head word it modifies. The role of the modifier is to describe or limit the head word (Mok, K. Sankaran, Lau, 2019). Obviously, the speaker B had omitted the measure word "shuāng" (pair) in the MEP. However, the message "this running shoe" was clearly conveyed to the listener. The language used by speaker B might not fulfill the structure of MEP, but the way of speaking is natural and understandable.

Another example of the natural language used can be seen in the conversation below:

Pair 2

Speaker A: Nǐ chuān jǐ hào de?

(What size do you wear?)

Speaker B: Wǒ chuān zhōng hào de.

(I wear size M.)

Speaker A: Zhè jiàn hăo ma?

(Is this piece [of cloth] good?)

Speaker B: Hěn hăokàn, wǒ hěn xǐhuan. Duōshao qián?

(Very good, I like it very much. How much?)

Speaker A: Zhè gè yào 75 kuài qián.

(This one RM75.)

In the last sentence of the conversation, speaker A used "zhè gè" (this one) to replace "zhè jiàn yiffu" (this piece of cloth). As explained by Storch (2002), "when the learners engage with tasks, they bring with them particular dispositions and notions of how the task might be approached". Therefore, the speaker A used the natural way to point out the object directly. 
The usage of "zhè gè" (this one) and "nà gè" (that one) can be categorized as linguistics element of natural language in authentic situation. They are useful for the non-native speakers to communicate effectively.

Findings for Social Interaction

(Learner-Centredness through communicative tasks)

This section presents answers to Research Question 2: How does task-based learning encourage social interaction?

According to Tudor (1992), the main feature of the learner-centered language teaching method is that it caters to learners' active participation in the development of their learning plans. In this study, when the respondents were doing the activities and tasks, they were developing their ability to communicate in Mandarin and to interact with native speakers. The social interaction between the respondents and the native speakers can be grouped into 3 themes: (a) bargain, (b) give description of product, and (c) small talk. The learnercentredness of respondents can be revealed through the excerpts from conversation transcripts below:

Pair 1 (Bargain)

Speaker A: Fúwùyuán, chǎoguǒtiáo hé làshā yígòng duōshao qián?

(Waiter, how much is the fried kuey teow and laksa?)

Speaker B: Yígòng RM25.

(Total is RM25.)

Speaker A: Wǒ yǒu huìyuánkă, kěyǐ zhékòu ma?

(I have membership card, can you give me discount?)

Speaker B: Yǒu huíyuànkă kěyǐ zhékòu 10 bāxiān.

(Yes, will give you $10 \%$ discount.)

Pair 2 (Bargain)

Speaker A: 5 gè wénjiànjiā hé liăng běn Huáyǔ shū yígòng 75 kuài qián.

(The total cost of 5 folders and 2 Mandarin books is RM75.)

Speaker B: Kěyǐ piányi diǎn ma?

(Can I get it cheaper?)

Speaker A: Èng...hăo ba, suàn nǐ 70 kuài qián hăo le.

(Hm...okay, just pay me RM70.)

Pair 3 (Description of Product)

Speaker A: Nǐ yào măi shénme yánsè de shǒubiăo?

(What colour watch do you want?)

Speaker B: Wǒ yào mǎi ž̌sè de.

(I want the purple one.)

Speaker $A$ : Zhè gè zěnmeyàng?

(How about this one?)

Speaker B: Zhè gè tài dà le.

(This one is too big.)

Speaker $A$ : Nà, zhè gè bijjiào xiăo, xǐhuan ma?

(Then, this is smaller, like it?) 
Speaker B: Hěn hăokàn, wǒ hěn xǐhuan.

(Very beautiful, I like it very much.)

Pair 4 (Description of Product)

Speaker A: Zhè shuāng xiézi tài xiǎo le. Nǐ shìyishì chuān liù hào de xiézi , hăo bùhăo?

(This pair [of shoes] is too small. Try on a size 6 shoes, okay?)

Speaker B: Hǎo'a! Zhè shuāng xiézi bǐjiào hăokàn, duì ma?

(Okay! This pair of shoes is more beautiful, right?)

Speaker A: Duì.

(Yes, they are.)

The 4 conversations above show the respondents' ability to interact effectively with the native speaker. They were able to bargain and describe the product. Undoubtedly, this is because they had obtained the skills from classroom. The learner-centredness was proven when the respondents were able to reflect on what they are learning and how they are learning it (Weimer, 2012).

Pair 5 (Small talk)

Speaker A: Huānyíng guānglín. Nǐ hăo.

(Welcome. Hello.)

Speaker B: Nǐ hăo.

(Hello.)

Speaker A: Nǐ chïfàn le ma?

(Have you eaten yet?)

Speaker B: Wǒ chī le, xièxie.

(Yes, I have eaten, thank you.)

"Nǐ chîfàn le ma? (Have you eaten yet?)" is always used to start the conversation among Chinese. Indeed, this expression is same as "how are you?" in English. Normally, people answer with "Wǒ chī le (I've eaten)", regardless they've eaten or not, it is similar to the reply "I'm fine thanks" in English even if people who answer does not actually feel good at the time. This opening speech is one kind of small talk in Mandarin.

Pair 6 (Small talk)

Speaker A: Xiăojiě, zhè gè báisè de wénjiànjiā zěnmeyàng? Hěn duō rén dōu xǐhuan măi zhè gè báisè de wénjiànjiā.

(Miss, how about this white folder? A lot of people like to buy this white folder.)

Speaker B: Èng....búcuò. Dànshì wǒ gèng xǐhuan nà gè lánsè de.

(Hm...not bad. But I prefer that blue one.)

The speaker B did not like the white folder, but she said she preferred something else; this is a way to show one's interest by using small talk. Obviously, the respondents in the study knew how to think and solve problem in social interaction based on the ability built-up after received explicit skill instruction. 
FINDINGS FOR CONSTRUCTIVISM (by rejecting traditional teaching and by Focusing on Form) This section presents answers to Research Question3: How does task-based learning encourage learning through constructivism?

The constructivism can be divided into rejecting the traditional teaching and focusing on form. According to Long (1991), "focus on form" is defined as: "overtly draws students' attention to linguistic elements as they rise incidentally in lessons whose overriding focus is on meaning or communication." That means learners' attention is focused on linguistics forms as they engage in the performance of tasks.

The examples of "focus on form" in this study can be noticed through the excerptions from conversation below:

Pair 1 (Telling money)

Speaker A: Wǒ hái yào yì pán là de chăoguǒtiáo. Yígòng duōshao qián?

(I also want a plate of spicy fried kway teow. How much is the total?)

Speaker B: Hăo. Yígòng 30.00 Lìngjí.

(Ok. Total is 30 Ringgit)

Speaker A: Wā! Hěn hăo. Fù nǐ 50.00 *kuài qián.

(Wow! Great. Pay you 50 *Ringgit)

Speaker B: Xièxie, zhăo nǐ 27 Lìngjí 50 Xiān.

(Thank you, here's 27 Ringgit 50 Sen for you.)

The basic unit of currency in Mandarin that respondents had learned in class is "kuài", "máo" and "fēn". Anyway, another form of telling money was also introduced to the respondents in the supplementary note of the textbook, that is "Lìngji" (Ringgit) and "Xiān" (Sen) in Malaysian context (Mok et al., 2021). Thus, the respondents were attracted and understood that the "Lìngjí" mentioned repeatedly by the native speaker equals to "kuài", so the respondents answered the shopkeeper with "kuài" which they learned more frequently in class. This shows that respondents did pay attention to the linguistic elements ("Lingji") in the conversation and replied using the form ("kuài") that they can communicate with the native speaker.

Pair 2 (Structure of sentence)

Speaker A: Kěyǐ zhékòu dào duōshao bāxiān?

(Can discount [up to] how many percent?)

Speaker B: Yùndòngxié kěyǐ zhékòu dào 50 bāxiān rúguǒ nǐmen yǒu huìyuánkă.

(Sport shoes can be discounted [up to] 50 percent if you have membership card.)

The structure of sentence "Yùndòngxié kěyǐ zhékòu dào 50 bāxiān rúguǒ nǐmen yǒu huìuánkă" is incorrect. The use of tail ("yùndòngxié kěyǐ zhékòu gāodá 50 bāxiān") and header ("rúguǒ nǐmen yǒu huìyuánkă") in this sentence are in opposite form. The correct form in Mandarin is "Rúguǒ nǐmen yǒu huìyuánkă, yùndòngxié kěyǐ zhékòu gāodá 50 bāxiān." This sentence is not in a proper form, but it's more communicative. 
This kind of rejecting traditional teaching can be found in other languages, such as English. As stated by George (2021), one of the differences of spoken English is the use of tail and header. For example:

A: That guy in the fashionable red jumper (header), is he our new teacher? (tail) and when in spoken form,

A: Is he our new teacher? (header) That guy in the fashionable jumper. (tail)

Tail and header give information to help listener understand what we are talking about in spoken English. The main difference is the header comes at the start of the sentence, whereas tail comes at the end of the sentence.

Pair 3 (Missing word)

Speaker A: Hăo, wǒmen yīqì qù fùqián ba!

(Good, let's go pay together!)

Speaker B: Hăo de, zǒu ba! Bùyào wàngjì nǐ de huiyuánkă.

(Okay, let's go! Do not forget your membership card.)

In the sentence of "Bùyào wàngjì nǐ de huìuánkă" (Do not forget your membership card), some words were missing between "wàngji”" (forget) and "nǐ de huìyuánkă" (your credit card).

The sentence is incomplete, it is omitted or ellipsis. The ellipsis is something commonly used in spoken language. It's when we leave words out of a sentence, but the meaning is still understood. Spoken language is often more casual, the grammar is more simple, mainly short sentences. Besides, as pointed out by Hasa (2016), spoken Language contains repetitions, incomplete sentences, interruptions, corrections, etc. Therefore, even though the sentence is incomplete, it stresses meaning over form. It fulfils the meaning of "task" as defined by Nunan (1989), "a piece of classroom work which involves learners in comprehending, manipulating, producing or interacting in the target language while their attention is principally focused on meaning rather than form".

In brief, the excerptions from conversation show that although respondents were able to perform activities and tasks within a task-based framework, they have not yet been able to truly integrate into and communicate with Chinese society. They were developing their ability to communicate in Mandarin and interact with native speakers through the task-based activities. In the long term, the respondents still need more practise and participate in more extracurricular activities to communicate with Mandarin-speaking Chinese to improve their Mandarin speaking proficiency.

\section{Conclusion}

\section{Summary of Findings and Discussions}

Authenticity

The task that learners completed allowed them to achieve a real outcome (buying everyday products and conversing with native speakers). This complies with the study by Meng (2020) who emphasized that situation is important in task-based learning, even if the real situation is not available especially in times of online learning. In addition to that, Rahmat, Mok, Lau \& Fan (2020) found that tasks that mirror real situations act as pseudo-authentic environment to maximise learning. 


\section{Social Interaction}

The task carried out by learners such as bargaining, describing products followed by small talk with the native speakers helped learners to engage in social interactions. This study is in accordance with the study by Rahmat, Mok, Lau \& Fan (2020) who also reported that peer interaction maximises learning.

\section{Constructivism}

The conversation that the learners made with the native speakers became creative because they (the learners) wanted to get their message across. Real situations with native speaker gave learners no choice but to create their own knowledge to made themselves understood. This also reported by Zhou (2016) who said that restructuring is often needed by learners to understand and be understood. In addition to that,

Chen \& Chung (2011) and Zhan \& Cheng (2014) reported that constant practice by learners gave them unlimited learning capacity. They had the chance to try out what they have learnt and then to improvise to suit their needs (Ju \& Mei, 2020).

\section{Pedagogical Implications}

The research findings can help Mandarin teachers improve or modify their teaching methods to adapt to the actual situation of Chinese society.

It also helps the writer of Mandarin textbook to improve the content of textbooks, such as adding extra tasks suitable to each lesson's goal after every lesson as an exercise to improve the student speaking skills. They also can add some extracurricular words which commonly used in native speakers' daily life.

In addition, the research findings also assist Mandarin language teachers choose or create appropriate animation video tasks to enable students to communicate more effectively and easily in Mandarin.

\section{Suggestions for Future Research}

This study is a pilot study that directly connects Malay undergraduates with native speakers of the Malaysian Chinese community to investigate the students' Mandarin language proficiency in real-life situation. For future research, it is recommended that researchers conduct a larger sample of research involving multiple campuses of the UiTM. In addition, students could be given various tasks in different location, such as the market, the workplace, etc., to interact with more native Mandarin speakers. The feedback from the industry would be valuable to gain more insight into the Mandarin proficiency of students.

\section{Acknowledgement}

The author would like to thank Research Management Centre (RMC), Universiti Teknologi MARA (UITM), Malaysia for the facilities and financial support under the grant with file no. 600-RMC/GPK 5/3 (018/2020).

\section{References}

Allen, J. R. (2008). Why learning to write Chinese is a waste of time: A modest proposal. Foreign Language Annals, 41(2), 237-251. http://doi.org/dv8m5d 
Bao, L. J., Shi, L. H., \& Sun, Y. H. (2008). Jiaoji yuanzexia de Hanyu cihui jiaoxue celue 交际原 则下的汉语词汇教学策略 (Strategies of Chinese vocabulary teaching in view of communication norms). Journal of Changchun University, 9, 100-102. https://bit.ly/3a9Py3k

Carless, D. (2009). Revisiting the TBLT versus P-P-P Debate: Voices from Hong Kong. Asian Journal of English Language Teaching, 19, 49-66. https://bit.ly/3FpbXZc

Chao, Y. R. (1925). A phonograph course in the Chinese national language. Shanghai: Commercial Press.

Chen, C. Y., \& Chung, W. L. (2011). Research on the learning effects of multimedia assisted instruction on Mandarin vocabulary for Vietnamese students: A preliminary study involving e- learning system. Educational Research Reviews, 6(17), 919-927. https://doi.org/10.5897/ERR11.166

Chen, L. G. (2006). Liyong jiaoxue keji rongru Huayuwen jiaoxue tisheng yuyan jiaoji nengli zhi yanjiu利用教学科技融入华语文教学提升语言交际能力之研究 (The Application of Teaching Technology Increase the Social Interaction Skills of Mandarin Language), presented at The 8th World Conference on Chinese Language, Taipei, 4, 21-41.

Cui, Y. H. (2008). Duiwai Hanyu jiaoxue sheji daolun 对外汉语教学设计导论(Introduction to Teaching Design in Chinese as a Foreign Language). Beijing: Beijing yuyan daxue chubanshe.

Ellis, R. (2009). Task-based language teaching: Sorting out the misunderstandings. International Journal of Applied Linguistics, 19(3), 221-246. https://doi.org/10.1111/j.1473-4192.2009.00231.x

Everson, M. E. (1988). Speed and comprehension in reading Chinese: Romanization vs. characters revisited. Journal of the Chinese Language Teachers Association, 23(2), 1-15. http://journal.clta-us.org

Everson, M. E. (1998). Word Recognition among Learners of Chinese as a Foreign Language: Investigating the Relationship between Naming and Knowing. Modern Language Journal, 82(2), $194-204$. doi: 10.1111/j.1540-4781.1998.tb01192.x

Everson, M. E. (2009). Literacy development in Chinese as a foreign language. In M. E.

Everson, \& Y. Xiao, Teaching Chinese as a foreign language (pp. 97-111). Boston, MA: Cheng \& Tsui Company.

Feldman, L. B., \& Siok, W. W. (1999). Semantic radicals in phonetic compounds: Implications FoR visual character recognition in Chinese. In J. Wang, A. W. Inhoff, \& H.-C. Chen (Eds.), Reading Chinese script: A cognitive analysis (pp. 19-35). Mahwah, NJ: Lawrence Erlbaum Associates.

George. (2021). 3 Differences Between Spoken English and Written English: Learn English with Cambridge. https://www.youtube.com/watch?v=Yg50bgJngH8

Guan, C. Q., Liu, Y., Chan, D. H. L., Ye, F., \& Perfetti, C. A. (2011). Writing strengthens orthography and alphabetic-coding strengthens phonology in learning to read Chinese. Journal of Educational Psychology, 103(3), 509-522. http://doi.org/bnf9fr

Halliday, M. A. K. (1973). Explorations in the Functions of Language. London: Edward Arnold.

Harrington, M., \& Jiang, W. (2013). Focus on the Forms: Form recognition practice in Chinese vocabulary learning. Australian Review of Applied Linguistics, 36(2), 132-145. http://www.nla.gov.au/openpublish/index.php/aral/article/viewFile/3070/3612

Hasa. (2016). Difference Between Spoken and Written Language. https://pediaa.com/difference-between-spoken-and-written-language/ 
Hayes, E. B. (1988). Encoding strategies used by native and non-native readers of Chinese Mandarin. The Modern Language Journal, 72(2), 188-195. http://doi.org/bp8nm2

Hymes, D. (1971). Competence and performance in linguistic theory. In Huxley, R., \& E. Ingram (Eds.), Language Acquisition: Models and Methods (pp. 3-28). London: Academic Press. Jafri, N., \& Abd Manaf, U. K. (2020). Looking into Students' Willingness to Communicate: A Case Study in Mandarin Language Learning. Universal Journal of Educational Research, 8(1A), 123-131. DOI: 10.13189/ujer.2020.081316

Jia, H. (2005). Jiaojifa zai duiwai Hanyu kouyu jiaoxue zhong de yunyong 交际法在对外汉语 口语教学中的运用 (Communication Skills in the Teaching of Mandarin Language). Journal of Changchun Education Institute, 3, 36-38. https://bit.ly/2YmG6aa

Jiang, L. P. (2009). Duiwai Hanyu jiaoxuelun 对外汉语教学论 (Theory of Teaching Chinese as a Foreign Language). Beijing: Beijing yuyan daxue chubanshe.

Ju, S. Y., \& Mei, S. Y. (2020). Students' Attitudes and Perceptions of Learning Mandarin Chinese via Animated Video. International Journal of Academic Research in Business and Social Sciences, 10(10), 567-579. http://dx.doi.org/10.6007/IJARBSS/v10-i10/7782

Khor, G. S., Lidia Ramirez Arriaga, \& Mah, B. Y. (2013). Errors Analysis in Hanyu Pinyin Pronunciation among the Undergraduates from Universiti Sains Malaysia (USM), Engineering Campus, presented at The Asian Conference on Language Learning Proceedings, Osaka, Japan. https://bit.ly/3BiNUIJ

Krashen, S., Terrell, T. (1983). The Natural Approach: Language Acquisition in the Classroom. London: Alemany Press.

Lave, J., \& Wenger, E. (1991). Situated learning: Legitimate peripheral participation. Cambridge University Press.

Li, D. P. (2017). Ji yu huati de duiwai Hanyu cihui jiaoxue yanjiu基于话题的对外汉语词汇教 学研究 (A Study of Topic-based Mandarin Vocabulary Teaching to Foreign Students). Central China Normal University Journal of Postgraduate, 24(3), 85-88. https://core.ac.uk/download/pdf/323948703.pdf

Lin, T. J., Wang, S. Y., Grant, S., Chien, C. L., \& Lan, Y. J. (2014). Task-based teaching approaches of Chinese as a foreign language in Second Life through teachers' perspectives. Procedia Technology, 13, 16-22. https://doi.org/10.1016/j.protcy.2014.02.004

Long, M. (1985). A role for instruction in second language acquisition: task-based language teaching. In K. Hyltenstam \& M. Pienemann (Eds.), Modelling and Assessing Second Language Acquisition (pp. 77-100). Clevedon: Multilingual Matters.

Long, M. (1991). Focus on form: A design feature in language teaching methodology. In K. de Bot, R. Ginsberg, \& C. Kramsch (Eds.), Foreign language research in cross-cultural Perspective (pp. 39-52). Amsterdam: John Benjamin.

Lu, J. J. (1984). Waiguoren xuexi Hanyu de yufa pianwu fenxi 外国人学习汉语的语法偏误分 析 (Analysis of grammatical errors in Mandarin for foreigners). https://www.wendangwang.com/doc/cf2fabc6ea9be6dd2bd31147/3

Lu, J. J. (2010). Duiwai Hanyu yuyin jiaoxue ji ge jiben wenti de zairenshi对外汉语语音教学 几个基本问题的再认识 (Re-understanding of Some Basic Questions Concerning Teaching Mandarin Phonetics to Foreign Learners). Journal Of Dali University, 9(5), 1-4. http://222.198.130.40:81/Qikan/Article/Detail?id=34298213\&from=Qikan_Article_De tail

Lü, B. S. (2005). Yuyan jiaoyu yu duiwai Hanyu jiaoxue 语言教育与对外汉语教学(Language Education and the Teaching of Mandarin Language as Second Language ). Waiyu jiaoxue yu yanjiu cubanshe. 
Lü, B. S. (2007). Hanyu he Hanyu zuo wei di-er yuyan jiaoxue 汉语和汉语作为第二语言教学 (Chinese and Teaching Chinese as a Second Language). Beijing: Beijing daxue chubanshe.

Mao, Z. (2012). The Application of Task-based Language Teaching to English Reading Classroom. Theory and Practice in Language Studies, 2(11), 2430-2438. doi: 10.4304/tpls.2.11.2430-2438

Meng, Y. Z. (2020). Qingjing jiaoxuefa zai duiwai Hanyu wangluo xinci jiaoxue zhong de yingyong - yi zhonggaoji shuiping de Hanyu xuexizhe wei jiaoxue duixiang 情景教学法 在对外汉语网络新词教学中的应用一一以中高级水平的汉语学习者为教学对象

(The Application of Situational Teaching Method in Teaching Internet New Words of Teaching Chinese as a Foreign Language - Using Intermediate and Advanced Level Chinese Learners as Teaching Objects). Jiaoyu yanjiu教育研究 (Education Research), 3(2), 138-139. DOI:10.32629/er.v3i2.2451

Mok, S. S., Lau, S. K., \& K. Sankaran, S. S. (2019). The Error Analysis of Learning Mandarin Endocentric Phrases among the Malay Students in Malaysia. International Journal of Modern Languages and Applied Linguistics, 3(2), 49-62. https://doi.org/10.24191/ijmal.v3i2.7645

Mok, S. S., Lau, S. K., Goh, C. S., Shamsudden, T. A., Lee, S. Y., \& Neo, Y. F. (2021). Chuji Huayu (er) 初级华语 (二) (Introductory Mandarin Level 2). Shah Alam: UiTM Press.

Nunan, D. (1989). Designing tasks for the communicative classroom. Cambridge, England: Cambridge University Press.

Nunan, D. (1991). Communicative Tasks and the Language Curriculum. TESOL Quarterly, 25 (2), 279 - 295. https://doi.org/10.2307/3587464

Packard, J. L. (1990). Effects of time lag in the introduction of characters into the Chinese language curriculum. The Modern Language Journal, 74(2), 167-175. http://doi.org/fnr5d2

Perfetti, A. C., Ying, L., \& Tan, L. H. (2005). The lexical constituency model: Some implications of research on Chinese FoR general theories of reading. Psychological Review, 112(1), 43-59. http://doi.org/c8m93v

Poole, F., \& Sung, K. Y. (2015). Three approaches to beginning Chinese instruction and

their effects on oral development and character recognition, Eurasian Journal of Applied Linguistics, 1(1), 59-75. https://ejal.info/three-approaches-to-beginning-chineseinstruction-and-their-effects-on-oral-development-and-character-recognition/

Rahmat, N. H., Mok, S. S., Lau, S. K., \& Fan, P. S. (2020). Experiential Learning In Mandarin Classrooms: The Case For Simulation. International Journal of Asian Social Science, 10(4), 171-180. DOI: 10.18488/journal.1.2020.104.171.180

Rubin, R. B., Rubin, A. M., \& Piele, L. J. (1949). Communication Research : Strategies and Sources, translated by Mokhtar Muhammad, UPENA UiTM.

Shen, H. H. (2005). An investigation of Chinese-character learning strategies among nonnative speakers of Chinese. System, 33(1), 49-68. http://dx.doi.org/10.1016/j.system.2004.11.001

Shi, J. W. (1998). Waiguo liuxuesheng 22 lei xiandai Hanyu jushi de xide shunxu yanjiu外国留 学生22类现代汉语句式的习得顺序研究 (A Study on the Acquisition Order of 22 Types of Modern Mandarin Sentence Patterns by Foreign Students), Shijie Hanyu jiaoxue 世界 汉语教学 (Chinese Teaching in the World), 4, 77-98.

http://gb.global.cnki.net/kcms/detail/detail.aspx?dbcode=CJFD\&filename=SJHY19980 4007\&dbname=CJFD9899 
Spada, N., \& Lightbown, P. (2008). Form-focused instruction: Isolated or integrated? TESOL Quarterly, 42(2), 181-207. https://doi.org/10.2307/40264447

Storch, N. (2002). Patterns of interaction in ESL pair work. Language Learning, 52, 119-158. http://dx.doi.org/10.1111/1467-9922.00179

Terrell, T. (1977). A Natural Approach to Second Language Acquisition and Learning. The Modern Language Journal, 61(7), 325-337. https://doi.org/10.2307/324551

Tong, H. J. (1986). Waiguoren xue Hanyu bingju fenxi 外国人学汉语病向分析 (Analysis of wrong sentences in Mandarin for foreigners). Beijing: Beijing yuyan xueyuan chubanshe.

Tudor, I. (1992). Learner-centredness in language teaching: Finding the right balance. System, 20(1), 31-44. https://doi.org/10.1016/0346-251X(92)90005-N

Tř́sková, H. (2017). Acquiring and teaching Chinese pronunciation. In I. Kecskes (Ed.), Explorations into Chinese as a Second Language, Educational Linguistics 31(pp. 3-30). DOI 10.1007/978-3-319-54027-6_1

Wang, J. Q. (1997). Hanyu zuowei di-er yuyan de xide yanjiu汉语作为第二语言的习得研究 (Research on the Acquisition of Mandarin as a Second Language). Beijing: Beijing yuyan wenhua daxue chubanshe.

Weimer, M. (2012). Five Characteristics of Learner-Centered Teaching. Faculty Focus. http://home.miracosta.edu/rfrench/documents/effective-teaching-strateg.pdf

Williams, Z. Y. (2013). The Use of Multimedia Material in Teaching Chinese as a Second Language and Pedagogical Implications [Masters Theses, University of Massachusetts, Amhearst]. https://scholarworks.umass.edu/cgi/viewcontent.cgi?article=2073\&context=theses

Willis, J. (1996). A flexible framework for task-based learning. In D. Willis \& J. Willis (Eds.), Challenge and change in language teaching, 52-62. Oxford, England: Heinemann.

$\mathrm{Xu}, \mathrm{P} ., \mathrm{\&}$ Jen, T. (2004). Penless Chinese language learning: A computer-assisted approach. Journal of Chinese Language Teachers Association, 40(2), 25-42.

http://journal.clta-us.org/

Yang, H. Y. (1996). Hanyu tingli shuohua jiaoxuefa 汉语听力说话教学法 (Method of Teaching Listening and Speaking Skills of Mandarin Language). Beijing: Beijing yuyan wenhua daxue chubanshe.

Ye, L. (2013). Shall we delay teaching characters in teaching Chinese as a foreign language? Foreign Language Annals, 46(4), 610-627. http://doi.org/xzj

Zhan, H., \& Cheng, H. (2014). The Role of Technology in Teaching and Learning Chinese Characters. International Journal of Technology in Teaching and Learning, 10(2). https://commons.erau.edu/publication/1097

Zhang, Y. Y. (2015). A Chinese Teacher's Exploration of Teaching Strategies for Support Class Students: An Action Research in a Western Sydney school [Master Thesis, University of Western Sydney]. https://bit.ly/3DfmbJI

Zhao, J. M. (2011). Dui wai Hanyu jiaoxue gailun 对外汉语教学概论 (Introduction to Teaching Mandarin as a Foreign Language). Beijing: Shangwu yinshuguan.

Zheng, C. (2007). Lun duiwai Hanyu kouyu jiaoxue de shixiaoxing论对外汉语口语教学的实 效性 (Efficacy of Oral Skills in Teaching Mandarin As Foreign Language). Journal of Shenyang Normal University, 6, 150-152. https://bit.ly/3lfmIFf

Zhou, Y. (2016). Applying task-based language teaching in introductory-level Mandarin language classes at The College of The Bahamas. The International Journal of Bahamian Studies, 22, 34-42. 
INTERNATIONAL JOURNAL OF ACADEMIC RESEARCH IN BUSINESS AND SOCIAL SCIENCES Vol. 11, No. 12, 2021, E-ISSN: 2222-6990 @ 2021 HRMARS

https://journals.sfu.ca/cob/index.php/files/article/viewFile/253/pdf_43 